\title{
Rectal Vancomycin-Resistant Enterococcus Colonization Before Admission to Neonatal Intensive Care Unit
}

\section{Yenidoğan Yoğun Bakım Ünitesine Yatış Öncesinde Saptanan Vankomisine Dirençli Enterokok Kolonizasyonu}

\author{
๑Yeşim Coşkun', @Şeyda Ignak² \\ 'Department of Pediatrics, Koc University School of Medicine, Department of Pediatrics Istanbul, Turkey \\ 2Department of Medical Biology, Bahcesehir University School of Medicine, Istanbul, Turkey
}

\begin{abstract}
Aim: Vancomycin resistant enterococci (VRE) colonization is an important issue for healthcare recipients. The aim of this study is to determine the prevalence of VRE colonization in patients at the admission to the neonatal intensive care unit (NICU).

Material and Method: In this retrospective study the medical records of patients who hospitalized to NICU between January 2010 to December 2019 were analyzed. At the admission, patients whose rectal cultures were detected as VRE colonization were evaluated for demographic characteristics for the risk factors of colonization.

Results: One thousand three hundred twenty-three patients were admitted to our NICU from different centers were enrolled. Rectal VRE colonization was observed in 60 of 1323 (4.54\%) patients. Sixty-five percent (39/60) of patients with rectal VRE colonization had no previous hospitalization history. Among these 60 patients 28 of them were admitted to our NICU in the first week of their life.

Conclusion: Although hospitalization still remains an important risk factor for VRE colonization, we found that there is also a high rate of VRE colonization in newborns without a history of hospitalization or frequent outpatient admissions to pediatrics departments. That is a worrisome status that suggests that colonization may be developed in low risk areas of the hospital such as delivery room, operating room or recovery room.
\end{abstract}

Keywords: Colonization, Enterococcus, neonatal intensive care unit, vancomycin resistance
Öz

Amaç: Vankomisine dirençli enterokok (VRE) kolonizasyonu sağlık hizmeti alanlar açısından önemli bir konudur. Bu çalışmanın amacı yenidoğan yoğun bakım ünitesine (NICU) başvuru sırasında hastalarda VRE kolonizasyonu prevalansını belirlemektir.

Gereç ve Yöntem: Bu retrospektif çalışmada, Ocak 2010 - Aralık 2019 tarihleri arasında NICU'ya yatan hastaların tıbbi kayıtları incelendi. Başvuruda rektal kültürleri VRE kolonizasyonu olarak tespit edilen hastalar kolonizasyonun risk faktörleri açısından demografik özellikler açısından değerlendirildi.

Bulgular: Hastanemiz yenidoğan yoğun bakım servisine bur süreçte 1323 hastanın değişik merkezlerden kabul edildiği görülmüştür. 1323 hastanın 60'ında (\% 4.54) rektal VRE kolonizasyonu gözlenmiştir. Rektal VRE kolonizasyonu olan hastaların \%65'inde (39/60) hastaneye yatış öyküsüne rastlanmamıştır. Rektal VRE kolonizasyonu saptanan 60 hastanın 18'inin (\%46) yaşamlarının ilk haftasında yoğun bakım ünitemize başvurduğu saptanmışıır.

Sonuç: Hastane ortamlarının VRE kolonizasyonu için önemli bir risk faktörü olduğu bilinmektedir. Çalışmamızda hastanede yatış öyküsü bulunmayan veya pediatri bölümlerine çok sayıda poliklinik başvurusu yapmamış yenidoğanlarda da yüksek VRE kolonizasyonuna rastlanmıştır. Bu durum hastanenin doğumhane, ameliyathane veya dinlenme odası gibi düşük riskli bölgelerinin de kolonizasyonun kaynağı olabileceğini düşündüren endişe verici bir durumdur.

Anahtar Kelimeler: Enterococcus, kolonizasyon, yenidoğan yoğun bakım, vankomisin direnci 


\section{INTRODUCTION}

Commensal Enterococcus spp. bacteria, although have low virulence, appears to be an important nosocomial agent especially in intensive care units of hospitals especially among immunosuppressed patients due to their resistance to environmental conditions, intrinsic resistance to various antibiotics and their ability to develop new resistance. Enterococci have been shown to cause bacteremia, surgical wound infections, peritonitis and endocarditis in every age group. ${ }^{[1-3]}$ Enterococcus faecalis (80-90\%) and Enterococcus faecium (10-15\%) are the most common agents which cause clinical infections in human. ${ }^{[4]}$ Enterococci can colonize the gastrointestinal system, respiratory system and urinary tract, skin and mucous membranes and show resistance due to excessive antibiotic use in the hospitals..$^{[5]}$ Services such as pediatrics wards, neonatal intensive care units (NICU), and pediatric hematology and oncology departments are high risk areas for Vancomycin resistant enterococci (VRE) colonization. Insufficient immune system of the neonates, wide spectrum antibiotic use due to nosocomial infections and prolonged hospital stay are the most important factors that increase the colonization of VRE strains among patients in NICU. ${ }^{[3,6]}$

In this study, the medical records of patients who hospitalized to NICU were analyzed in terms of rectal VRE colonization and demographic characteristics such as gestational week (GW), birth weight (BW), gender, previous admissions, days of hospitalization. The authors aimed to determine the prevalence of VRE colonization at the admission, the demographic characteristics of the VRE colonized patients, and the distribution of VRE colonization according to the years.

\section{MATERIAL AND METHOD}

Medical records of 2439 patients who admitted to NICU of Bahcesehir University School of Medicine between January 2010 and December 2019 for various medical problems were examined. The medical records of 1323 patients who were admitted to NICU from other centers were evaluated in terms of demographic characteristics such as age, gender, GW, BW, previous admissions to any centers and hospitalization. Our study was approved by Bahcesehir University Clinical Research Ethics Committee (Protocol number 2020/06-01).

\section{Microbiological analysis}

Rectal swab samples were collected on Stuart transport medium. Swab samples inoculated on the VRE Agar Base, which was containing $6 \mu \mathrm{g} / \mathrm{ml}$ vancomycin. After 24-48 hours of incubation at $37^{\circ} \mathrm{C}$, the petri dishes were evaluated in terms of growing colonies. Gram positive cocci shaped, catalase test negative colonies were identified at the species level and antibiotic susceptibility tests performed by VITEK 2 automated system (bioMerieux, France).

\section{RESULTS}

One thousand three hundred twenty-three patients who were admitted to NICU from other centers and did not have any contact with our center previously were enrolled. Vancomycin resistant enterococci colonization was found in 60 out of 1323 patients in standard rectal VRE cultures performed at the admission to NICU. Of the 60 patients with VRE colonization, 39 had no previous hospitalizations history, but each of these patients had different outpatient visits (1-5 times). The characteristics of the patients are shown in Table 1.

\begin{tabular}{|c|c|c|c|}
\hline \multirow{2}{*}{ Characteristics } & & VRE (+) n:60 & VRE (-) n:1263 \\
\hline & & Mean \pm SD or $n(\%)$ & Mean \pm SD or $n(\%)$ \\
\hline Gestation week & & $37.3 \pm 3$ & $32 \pm 4$ \\
\hline Birth weight (g) & & $2917 \pm 671.3$ & $2340 \pm 465.2$ \\
\hline \multirow{2}{*}{ Gender } & Female & $28(46.6)$ & $703(55.6)$ \\
\hline & Male & $32(53.4)$ & $560(44.3)$ \\
\hline \multirow{2}{*}{ Birth type } & Caesarean & $41(68.3)$ & $976(77.3)$ \\
\hline & Normal delivery & 19 (31.7) & $287(22.7)$ \\
\hline $\begin{array}{l}\text { Age at the } \\
\text { time of } \\
\text { hospitalization }\end{array}$ & $\begin{array}{l}<24 \text { hours } \\
1-7 \text { days } \\
<7 \text { days }\end{array}$ & $\begin{array}{c}1(1.67) \\
27(45) \\
32(53.3)\end{array}$ & $\begin{array}{l}754(59.7) \\
293(23.2) \\
216(17.1)\end{array}$ \\
\hline $\begin{array}{l}\text { NICU admission } \\
\text { route }\end{array}$ & $\begin{array}{l}\text { Other centers } \\
\text { Home }\end{array}$ & $\begin{array}{l}21(35) \\
39(65)\end{array}$ & $\begin{array}{l}387(30.6) \\
876(69.4)\end{array}$ \\
\hline
\end{tabular}

We found a significant rise in VRE colonization in every year which is shown in Figure 1.

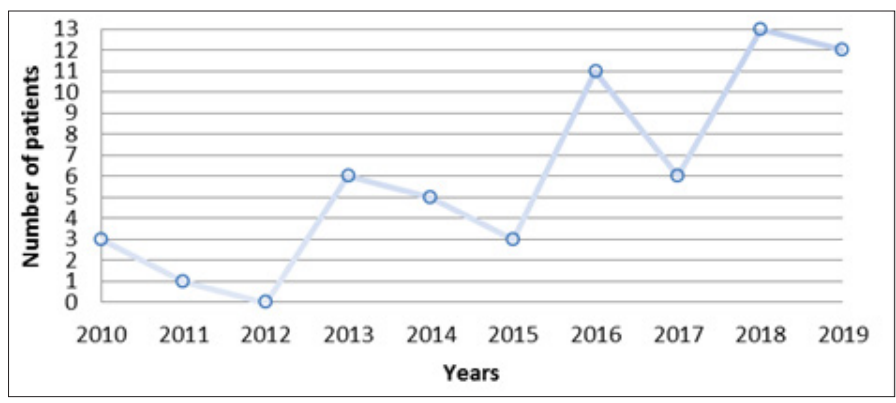

Figure 1. Distribution of VRE colonization in patients according to years

\section{DISCUSSION}

This study aims to determine the prevalence and risk factors of VRE colonization in patients who were hospitalized to NICU from other centers or home. According to our results, rectalVRE colonization was found in 60 of 1323 (4.54\%). It is noteworthy that $65 \%(39 / 60)$ of patients with rectal VRE colonization had no previous hospitalization history. We also found that, 28 (46\%) patients with rectal VRE colonization were admitted to $\mathrm{NICU}$ in the first 7 days of life. 
Wide spectrum antimicrobial use, severe underlying diseases or long hospital stays are known to be the major risk factors for carriage of drug resistant organisms such as VRE. ${ }^{[7]}$ According to a meta-analysis conducted by Ziakas et al. ${ }^{[8]}$ the frequency of VRE colonization which was observed during hospitalization in different intensive care units was $6.3-9.6 \%$. In the same study, the frequency of infection due to VRE colonization was $0-45 \%$, whereas it was consistently $<2 \%$ in patients without colonization. VRE colonization during hospitalization was found as $12.3 \%$ in US studies, $2.7 \%$ in European and $5.3 \%$ in Asian studies.These geographical differences of drug resistant bacteria can be explained by the different antibiotic usage policies of countries, compliance with isolation and infection control practices, and the cultural differences in the behavior of health care workers..$^{[9,10]}$ In our study we determined the rate of VRE colonization among neonates at admission in order to rule out the colonization during our NICU. As our knowledge, there is a large set of data on outbreaks or colonization rates in intensive care units but to a lesser extent in community-derived ones. Landete et al. ${ }^{[1]]}$ collected 41 fecal samples from 21 breastfed healthy infants younger than 6 months who had no perinatal problems and prescribed antibiotics at least 3 months from the study. Of the 41 isolates, which showed gram-positive and catalase-negative morphology, 26 (from 15 infants) were identified as E. faecalis and 15 (from 7 infants) as E. Faecium. None of the isolates showed resistance to vancomycin. Thacker et al. ${ }^{[12]}$ conducted a study with 618 patients at admission to the pediatric oncology unit or pediatric ward, which included 528 children with hematological malignancies and 90 children with solid tumors. Rectal swabs were sent to determine the colonization with multidrug-resistant organisms. Sixty-five (11.4\%) had vancomycin-resistant enterococci in baseline cultures. In our study, we found that of 1323 neonates, 60 were colonized with VRE and $65 \%$ patients had no history of hospitalization which means there is always high risk for VRE colonization even though the neonates are not hospitalized.

In a review study containing data from 74 published studies about nosocomial colonization and infection by multiresistant organisms, the common risk factors were found as underlying severe disease and high severity of illness, inter-institutional transfer of the patient, long hospital stay, exposure to invasive devices and exposure to wide spectrum antimicrobial drugs. None of our patients had history of exposure to invasive devices or wide spectrum antibiotics use, moreover $46.6 \%$ of them were in the first week of their life. It is known that long hospitalization duration is an important risk factor for VRE colonization. ${ }^{[13]}$ In our study, $35 \%$ of patients with VRE colonization were transferred to our NICU from different centers. Among those patients, 12 of them (57\%) were in the first week of their lives. Although $65 \%$ of the patients had no previous hospitalization history (admitted from home), each of them had different numbers of outpatient visit history. Moreover one neonate was admitted to our NICU because of neonatal sepsis in the first day of life and VRE colonization was detected. This neonate was born via normal vaginal delivery at 40 weeks of gestation. It is known that enterococci is one of the first few bacteria that colonize primarily in the neonatal digestive system via originating from the mother's vaginal or gastrointestinal flora. ${ }^{[14]}$ Subramanya et al. ${ }^{[15]}$ reported one early onset septicemia case by vankomisin resistant Enterococcus faecium. They found the same VRE strain from blood samples of the neonate and stool speciemens of the mother at the same time and indicated that maternal gut colonization caused neonatal sepsis. We did not investigate the origin of the VRE strain via taking samples from mother or from the center where the birth took place. In our opinion, VRE colonization among our objects, which was detected very early of their lives, may be caused by colonization of the mother or the environment such as delivery room.

Some VRE colonizations may cause severe VRE infections, while some remain as asymptomatic carriers. Akturk et al. ${ }^{[16]}$ found that rectal VRE colonization was detected in 12\% (200/1671) of patients who hospitalized in NICU and systemic VRE infection developed in $3 \%(6 / 200)$ of patients with VRE colonization for an average of 9 days (range: 3-58 days). Benzer et al. ${ }^{[6]}$ performed rectal VRE cultures in hospitalized neonates after they diagnosed urinary tract infection in a preterm infant due to VRE in NICU and showed that of 133 patients, $40 \%$ had VRE colonization without any infection. Symptom-free colonization may last for a long time and serve as a reservoir for the transmission of VRE to other patients. ${ }^{[17]}$ It is known that one of the most important cause of spreading VRE in hospitals is associated with unrecognized prolonged fecal carriage. ${ }^{[18]}$ The asymptomatic carriage of VRE and the absence of an effective decolonization procedure maintain the endemicity of VRE in health care facilities. ${ }^{[19]}$ It is also known that this colonization may be a reservoir for transmission to other patients and play an important role in increased morbidity, mortality and healthcare costs. $^{[20]}$

This study had some limitations. Firstly, it is a retrospective study and we did not have a possibility to access to the previous data of the patients prior to admission to our NICU. Therefore, we were not able to reach reliable causes about the origin of VRE colonization. Secondly, we were not able to take specimens from mother to determine the origin of VRE colonization.

Although VRE colonization rate was $4.54 \%$ in patients admitted to our NICU, we found that the number of patients with VRE colonization were increased year after year. Moreover, $65 \%$ of patients with rectal VRE colonization had no previous hospitalization history but they had several times outpatient visit history and $46 \%$ of them were in the first week of their lives. That is a worrisome status that suggests colonization may be developed in delivery room, operating room or recovery room which are not known as high risk areas of the health care facilities or from the already colonized mother. In our opinion, although our study does not reflect the status of the health care facility induced VRE colonization or the community induced VRE colonization, multicenter studies should be done in order to determine more reliable rates of early VRE colonization during neonatal period. 


\section{ETHICAL DECLARATIONS}

Ethics Committee Approval: The study was approved by Bahcesehir University Clinical Research Ethics Committee (Protocol number 2020/06-01).

Informed Consent: Because the study was designed retrospectively, no written informed consent form was obtained from patients.

Referee Evaluation Process: Externally peer-reviewed.

Conflict of Interest Statement: The authors have no conflicts of interest to declare.

Financial Disclosure: The authors declared that this study has received no financial support.

Author Contributions: All of the authors declare that they have all participated in the design, execution, and analysis of the paper, and that they have approved the final version.

\section{REFERENCES}

1. Butler KM. Enterococcal infection in children. Semin Pediatr Infect Dis 2006;17(3):128-39.

2. Bilikova E, Koprnova J, Hafed BM et al. Nosocomial enterococcal infection in neonates. Int J Infect Dis 2004;8(2):127-9.

3. Iosifidis E, Evdoridou I, Agakidou E et al. Vancomycin-resistant Enterococcus outbreak in a neonatal intensive care unit: epidemiology, molecular analysis and risk factors. Am J Infect Control 2013;41(10):85761.

4. Sood S, Malhotra M, Das BK et al. Enterococcal infections \& antimicrobial resistance. Indian J Med Res 2008;128(2):111-21.

5. Tünger Ö. Vankomisine dirençli enterokok infeksiyonlarının tedavisinde eski ve yeni tedavi seçenekleri. ANKEM Derg 2012;26(4):215-27.

6. Benzer D, Yavuzcan Öztürk D, Gürsoy $T$ et al. Vancomycin-resistant enterococcus colonization in neonatal intensive care unit: prevention and eradication experience. Mikrobiyol Bul 2012;46(4):682-8.

7. Matar MJ, Tarrand J, Raad I et al. Colonization and infection with vancomycin-resistant Enterococcus among patients with cancer. Am J Infect Control 2006;34(8):534-6.

8. Ziakas PD, Thapa R, Rice LB et al. Trends and significance of VRE colonization in the ICU: a meta-analysis of published studies. PLoS One 2013;8(9):e75658.

9. Borg MA, Camilleri L, Waisfisz B. Understanding the epidemiology of MRSA in Europe: do we need to think outside the box?. J Hosp Infect 2012;81(4):251-6.

10. Pogorzelska M, Stone PW, Larson EL. Certification in infection control matters: Impact of infection control department characteristics and policies on rates of multidrug-resistant infections. Am J Infect Control 2012;40(2):96-101.

11. Landete JM, Peirotén Á, Medina $M$ et al. Virulence and Antibiotic Resistance of Enterococci Isolated from Healthy Breastfed Infants. Microb Drug Resist 2018;24(1):63-9.

12. Thacker N, Pereira N, Banavali SD et al. Alarming prevalence of communityacquired multidrug-resistant organisms colonization in children with cancer and implications for therapy: A prospective study. Indian J Cancer 2014;51(4):442-6.

13. Shorman M, Al-Tawfiq JA. Risk factors associated with vancomycinresistant enterococcus in intensive care unit settings in saudi arabia. Interdiscip Perspect Infect Dis. 2013;2013:369674. .

14. Milani C, Duranti S, Bottacini F et al. The First Microbial Colonizers of the Human Gut: Composition, Activities, and Health Implications of the Infant Gut Microbiota. Microbiol Mol Biol Rev 2017;81(4):e00036-17.
15. Subramanya SH, Amberpet R, Chaudhary D et al. Neonatal sepsis due to glycopeptide resistant Enterococcus faecium from colonized maternal gut- rare case evidence. Antimicrob Resist Infect Control 2019;8:29.

16. Akturk $H$, Sutcu $M$, Somer A et al. Vancomycin-resistant enterococci colonization in a neonatal intensive care unit: who will be infected?J Matern Fetal Neonatal Med 2016;29(21):3478-82. 17.

17. Sohn KM, Peck KR, Joo EJ et al. Duration of colonization and risk factors for prolonged carriage of vancomycin-resistant enterococci after discharge from the hospital. Int J Infect Dis 2013;17(4):e240-6.

18. Martone WJ. Spread of vancomycin-resistant enterococci: why did it happen in the United States? Infect Control Hosp Epidemiol 1998;19(8):539-45.

19. Cheng VC, Chen JH, Tai JW, et al. Decolonization of gastrointestinal carriage of vancomycin-resistant Enterococcus faecium: case series and review of literature. BMC Infect Dis. 2014;14:514.

20. Song X, Srinivasan A, Plaut D et al. Effect of nosocomial vancomycinresistant enterococcal bacteremia on mortality, length of stay, and costs. Infect Control Hosp Epidemiol 2003;24(4):251-6. 